\title{
Analisis Energi Potensial Gempabumi pada Zona Subduksi Wilayah Bali
}

\section{Analysis of Earthquake Potential Energy in the Bali Subduction Zone}

\author{
Ni Putu Juliyant Ananda Rika Pangastuti ${ }^{1 *}$, Komang Ngurah Suarbawa ${ }^{1}$, I Ketut Putra ${ }^{1}$, \\ Ni Luh Desi Purnami ${ }^{2}$
}

${ }^{1}$ Program Studi Fisika, Fakultas Matematika dan Ilmu Pengetahuan Alam, Universitas Udayana, Kampus Bukit Jimbaran, Badung, Bali, Indonesia 80361

${ }^{2}$ Stasiun Geofisika Kelas II, Jl. Pulau Tarakan No. 1, Sanglah, Denpasar, Bali, Imdonesia (80361)

Email: JJuliyantanandarika@gmail.com; suarbawa@unud.ac.id; putra_jongrang@ rocketmail.com

\begin{abstract}
Abstrak - Telah dilakukan penelitian analisis energi potensial gempabumi pada zona subduksi di wilayah Bali, yang bertujuan untuk mengetahui indeks seismisitas, a-value, b-value, periode ulang serta energi potensial gempabumi di wilayah Bali pada koordinat $114,2^{\circ}-115,9^{\circ}$ BT dan $11,7^{\circ}-7,5^{\circ}$ LS. Data gempabumi yang digunakan berupa tang gal dan waktuterjadinya gempabumi, koordinat gempabumi berupa bujur dan lintang, kedalaman gempabumi dan magnitudo. Penelitian dilakukan dengan menggunakan data sekunder berasal darikatalog gempabumi USGS(United State Geological Survey) dari tahun 1970-2020 dengan magnitudo 3 hingga 10. Data dimodelkan menggunakan software Arc Gis untuk memperoleh peta seismisitas. Perhitungan parameter gempabumi seperti indeks seismisitas, avalue, b-value, periode ulang gempabumi serta energi potensial gempabumi diperoleh dengan menggunakan metodeleast square. Dari hasil pengolahan data diperoleh bahwa a-value sebesar 5,3 dan $b$-value sebesar -0,74, indeks seismisitas sebesar 0,083 serta mempunyai estimasi periode ulang gempabumi dengan magnitudo $M_{0}$ yang diujikan $6 M_{b}$ sebesar 12 tahun. Energi potensial gempabumi untuk zona subduksi tersebut yaitu $3,616 \times 10^{14} \mathrm{~J}$. Dengan adanya energipotensial gempabumi ini pada zona subduksi di wilayah Balimenunjukan adanya kawasan seismic gapartinya kawasan inimenyimpan akumulasi energi gempabumi yang besar. Energi yang tersimpan ini dapat berpotensi menjadi gempabumi sedang pada kawasan zona subduksi di wilayah Bali.
\end{abstract}

Kata Kunci: Gempabumi, magnitudo, subduksi, metode least square, energi potensial gempabumi

\begin{abstract}
Research has been carried out to analyze the potential energy of earthquakes in the subduction zone in the Bali region, which aims to determine the seismicity index, a-value, $b$-value, retur period and earthquake potential energy in the Bali region atcoordinates $114.2^{\circ}-115.9^{\circ}$ east and $11.7^{\circ}$ $7.5^{\circ}$ south. Earthquake data used in the form of the date and time of the earthquake, earthquake coordinates in the form of longitude and latitude, earthquake depth and magnitude. The study was conducted using secondarydata from the USGS(United State Geological Survey) earthquake catalog from 1970-2020 with a magnitude of 3 to 10. The data was modeled using Arc Gis software to obtain seismicity map. Calculation of earthquake parameters such as seismicity index, $a$-value, $b$-value, earthquake return period and earthquake potentialenergywere obtained using theleast square method. From the results of data processing, is found that the a-value is 5.3 and the $b$-value is -0.74, the seismicityindex is 0.083 and estimated return period of an earthquake with a magnitude of $M_{0}$ tested at 6 $M_{b}$ for 12 years. The potential energy of the earthquakefor the subduction zone is $3.616 \times 10^{14} \mathrm{~J}$. With the potential energy of this earthquake in the subduction zone in the Bali region, it shows that there is a seismic gap area, meaning that this area stores a large accumulation of earthquake energy. This stored energy has the potential to become a moderate earthquake in the subduction zone area in the Bali region.
\end{abstract}

Keywords: Earthquake, magnitudo, subduction, least square method, earthquake potential energy

\section{Pendahuluan}

Pulau Bali merupakan daerah yang rawan terhadap kejadian gempabumi. Hal ini disebabkan karena 
daerah Bali diapit oleh dua zona penyebab gempabumi, yaitu di wilayah Bali selatan merupakan daerah pertemuan dua lempeng bumi (zona subduksi) yakni lempeng Eurasia dengan Indo-Australia serta akibat adanya subduksi ini menghasilkan efek berupa struktur geologi sesar aktif (back arc thrust) di wilayah Bali utara [1]. Zona subduksi yang membentang di kawasan Pulau Bali merupakan kaw asan seismic gap, artinya kawasan ini menyimpan akumulasi stress yang tinggi, akumulasi stress yang tinggi berkorelasi dengan energi gempabumi yang besar [2].

Energi gempabumi dapat dibagi menjadi dua macam, yaitu energi gempabumi yang dilepaskan setiap tahun dan energi yang disimpan (energi ekspektasi). Energi potensial gempabumi merupakan potensi energi yang menghasilkan gempabumi akibat adanya energi ekspektasi yang tidak dilepaskan. Untuk mengetahui energi potensial gempabumi suatu wilayah, maka perlu dilakukan perhitungan mengenai parameter keaktifan gempabumi berupa indeks seismisitas, a-value, b-value serta periode ulang gempagempa besar yang terjadi di wilayah penelitian [3]. Selain itu salah satu parameter sumber gempabumi yang penting adalah magnitudo, dimana dapat diperoleh informasi seberapa besar energi yang dilepaskan ketika terjadi gempabumi dengan melakukan konversi magnitudo terhadap energi. Metode yang dapat digunakan untuk menghitung parameter keaktifan gempabumi serta energi potensial gempabumi salah satunya adalah metode least square [4].

Berdasarkan uraian tersebut, penulis ingin melakukan penelitian untuk mengetahui Energi potensial gempabumi di kawasan zona subduksi Pulau Bali karena energi ini suatu waktu bisa dilepaskan dalam bentuk gempabumi berkekuatan besar. Energi gempabumi ini nantinya dapat digunakan dalam upaya mitigasi bencana serta dapat memperkecil dampak yang negatif dari gempabumi seperti kerusakan bangunan, korban jiwa dan sebagainya akibat gempabumi di wilayah Bali.

\section{Landasan Teori}

\subsection{Gempabumi}

Gempabumi adalah peristiwa bergetarnya bumi akibat pelepasan energi di dalam bumi secara tiba-tiba yang ditandai dengan patahnya lapisan batuan pada kerak bumi. Akumulasi energi penyebab terjadinya gempabumi dihasilkan dari pergerakan lempeng-lempeng tektonik. Energi yang dihasilkan dipancarkan kesegala arah berupa gelombang gempabumi sehingga efeknya dapat dirasakan sampai ke permukaan bumi. Berdasarkan penyebabnya gempabumi diklasifikasikan menjadi empat jenis yaitu gempabumi tektonik, gempabumi vulkanik, gempabumi reruntuhan dan gempabumi buatan [5].

\subsection{Parameter sumber dan keaktifan gempabumi}

Parameter sumber gempabumi merupakan hasil dari pengumpulan, pengolahan, dan analisis informasi seismik yang diperoleh dari kejadian gempabumi. Parameter sumber gempabumi yaitu [6]:

a. Episenter merupakan titik di permukaan bumi yang merupakan reflektifitas tegak lurus dari hiposenter. Lokasi episenter dibuat dalam koordinat kartesian permukaan bumi.

b. Hiposenter merupakan pusat gempabumi yang berada di dalam permukaan bumi.

c. Waktu kejadian gempabumi merupakan waktu dimana pelepasan energi pertama kali terjadi pada lempeng tektonik bumi yang mengalami tekanan akibat tumbukan atau gesekan dan dinyatakan dalam hari, tanggal, bulan, tahun, jam, menit, detik dalam satuan UTC (Universal Time Coordinated).

d. Ukuran dari kekuatan gempa disebut magnitudo, yaitu parameter gempa yang mengukur besarnya energi gempa yang dilepaskan dari sumbernya. Nilai magnitudo diperoleh dari amplitudo dan periode gerakan tanah atau dari durasi sinyal yang diukur pada rekaman instrumental [1]. Umumnya terdapat beberapa skala magnitudo yang digunakan yaitu magnitudo lokal $\left(\mathrm{M}_{1}\right)$, magnitudo badan $\left(\mathrm{M}_{\mathrm{b}}\right)$, magnitudo permukaan $\left(\mathrm{M}_{\mathrm{s}}\right)$, dan magnitudo momen $\left(\mathrm{M}_{\mathrm{w}}\right)$. Perhitungan a-value, b-value, indeks seismisitas serta periode ulang gempabumi dalam penelitian ini akan menggunakan magnitudo momen $\left(\mathrm{M}_{\mathrm{w}}\right)$ dan untuk perhitungan energi gempabumi akan menggunakan magnitudo permukaan $\left(\mathrm{M}_{\mathrm{b}}\right)$. Magnitudo yang diperlukan untuk satu tipe data yang sama yaitu $\mathrm{M}_{\mathrm{w}}$ yang tidak tersedia pada katalog kejadian gempa. Untuk itulah diperlukan konversi yang menghubungkan beragam tipe magnitudo. Konversi magnitudo untuk wilayah Indonesia mengadaptasi metode yang digunakan oleh Scordilis seperti ditunjukkan oleh Persamaan 1, 2, 3 dan 4 [7]. Konversi $\mathbf{M}_{\mathrm{b}}$ ke $\mathbf{M}_{\mathrm{w}}$ menggunakan Persamaan (1), konversi $M_{s}$ ke $M_{w}$ menggunakan Persamaan (2), konversi $M_{1}$ ke $M_{b}$ menggunakan 
Persamaan (3), dan hubungan antara $\mathrm{M}_{\mathrm{s}}$ dengan $\mathrm{M}_{0}$ menggunakan Persamaan (4).

$$
\begin{aligned}
& M_{w}=1,0107 M_{b}+0,0801 \\
& M_{w}=0,0616 M_{s}+2,476 \\
& M_{b}=0,125\left(M_{l}\right)^{2}-0,389\left(M_{l}\right)+3,513 \\
& \log _{0}=1,5 M_{s}+16,1
\end{aligned}
$$

Untuk konversi $\mathrm{M}_{\mathrm{l}}$ ke $\mathrm{M}_{\mathrm{w}}$ tidak perlu dilakukan karena magnitudo lokal dengan magnitudo momen memiliki nilai yang hampir sama [7].

Parameter keaktifan gempabumi dapat berupa keaktifan seismik (a-value), kerapuhan batuan (bvalue), indeks seismisitas dan periode ulang kejadian gempabumi [8]. Parameter a-value merupakan parameter seismik yang dipengaruhi oleh banyak data dan luas daerah penelitian. Arti fisis poin a yaitu menyatakan tingkat keaktifan seismisitas disuatu daerah yang sedang diamati. Semakin besar nilai a semakin tinggi pula keaktifan seismisitas di daerah tersebut [1]. Arti fisis poin b value berhubungan dengan keadaan tektonik di daerah yang sedang diamati dimana terjadi gempa bumi dan tergantung dari sifat batuan setempat. Semakin besar harga b, maka daerah tersebut semakin mudah terjadi gempabumi [13]. Indeks seismisitas adalah sebuah parameter fisis yang menggambarkan jumlah total kejadian gempabumi yang berlangsung dalam periode satu tahun. Perhitungan indeks seismisitas memakai persamaan berikut [9].

$$
N=10^{(a-\log (b \ln 10)-\log \Delta t-b M)}
$$

Periode ulang gempabumi adalah perkiraan waktu perulangan gempa yang pernah terjadi dengan kekuatan yang sama di suatu daerah tertentu. Nilai periode ulang gempabumi dapat dihitung dengan menggunakan persamaan sebagai berikut [10]

$$
\theta=\frac{1}{N}
$$

\subsection{Metode least square}

Prinsip dari metode least square atau kuadrat terkecil adalah meminimumkan jumlah kuadrat penyimpangan nilai variabel bebasnya dengan nilai trend. Metode ini digunakan untuk data-data yang mempunyai hubungan korelasi linier [10]. Adapun persamaan trend dengan metode least square, yaitu:

$$
Y=a+b X
$$

Variabel $\mathrm{Y}$ adalah nilai trend pada periode tertentu, $\mathrm{X}$ merupakan periode waktu, a adalah intersep yaitu besarnya nilai $\mathrm{Y}$, bila nilai $\mathrm{X}=0$, dan $\mathrm{b}$ adalah slope garis trend, yaitu perubahan variabel $\mathrm{Y}$ untuk setiap perubahan variabel X. Nilai a dan b masing-masing dihitung menggunakan Persamaan (8) dan (9) [10].

$$
\begin{aligned}
& b=\frac{n \sum X_{i} Y_{i}-\sum X_{i} \sum Y_{i}}{n \sum X_{i}^{2}-\left(\sum X_{i}\right)^{2}} \\
& a=\frac{\sum X_{i}\left(\sum X_{i}\right)^{2}-\sum X_{i} \sum\left(X_{i} Y_{i}\right)}{n \sum X_{i}^{2}-\left(\sum X_{i}\right)^{2}}
\end{aligned}
$$

\subsection{Energi gempabumi}

Bentuk energi yang dilepaskan saat terjadinya gempabumi antara lain adalah energi deformasi gelombang. Energi deformasi dapat dilihat pada perubahan bentuk volume sesudah terjadinya gempabumi seperti tanah naik. Sedangkan energi gelombang akan menggetarkan medium elastik di sekitarnya dan akan menjalar ke segala arah. Melalui hubungan antara magnitudo dan energi, energi seismik (E) yang dihasilkan oleh sumber gempabumi sebagai gelombang seismik dapat diestimasi. Hubungan antara E dan magnitudo yaitu [12]:

$$
\log E=11,8+1,5 M_{s}
$$




$$
\log E=5,8+2,4 M_{b}
$$

Energi gempa dapat dikelompokkan menjadi tiga tahap atau siklus berdasarkan sifat pengulangannya. Inter-seismik pertama adalah energi yang terakumulasi. Co-seismik kedua adalah pelepasan energi. Energi gempa sisa ketiga pasca seismik dilepaskan secara perlahan dalam kurun waktu tertentu hingga tahap keseimbangan awal kembali. Berdasarkan tiga energi tersebut dapat diketahui seberapa besar energi potensial dalam suatu segmen. Energi potensial adalah energi yang disimpan di bawah kerak bumi, yang sewaktu-waktu dapat terlepas dalam bentuk gempa bumi. Energi gempa yang dihasilkan bergantung pada kondisi tegangan tektonik lokal dan aktivitas seismik [11].

Energi gempabumi yang lepas pertahun dapat ditentukan dengan Persamaan (13) [9].

$$
E_{1}=\frac{\sum X_{i}\left(\sum X_{i}\right)^{2}-\sum X_{i} \sum\left(X_{i} Y_{i}\right)}{n \sum X_{i}^{2}-\left(\sum X_{i}\right)^{2}}
$$

Dimana $Y_{i}$ adalah energi gempabumi kumulatif, $E_{1}$ adalah jumlah energi lepas gempabumi pertahun (erg/tahun) dan $X_{i}$ selang waktu dalam tahun dimana tahun ke-1 dimulai dari tahun 1970.

Adapun energi total pertahun dapat diperoleh dari menjumlahkan energi gempabumi yang lepas pertahun dengan energi ekspektasi total pertahun dengan Persamaan (14) [12].

$$
E_{\text {tot }}=E_{1}+E_{2}
$$

Dengan $\mathrm{E}_{\text {tot }}$ adalah energi total (erg/tahun), $\mathrm{E}_{1}$ adalah energi lepas pertahun (erg/tahun) dan $\mathrm{E}_{2}$ energi ekspektasi total pertahun (erg/tahun). Sedangkan untuk memperoleh energi potensial gempabumi dengan cara mengurangi energi total seharusnya dilepaskan $\left(E_{a}\right)$ dengan energi yang telah dilepaskan $\left(E_{b}\right)$. Adapun persamaan untuk menghitung besarnya energi potensial gempabumi adalah [12]:

$$
E_{p g}=E_{a}-E_{b}
$$

dan

$$
E_{a}=t \times E_{t o t}
$$

Dengan $\mathrm{E}_{\mathrm{pg}}$ adalah energi potensial gempabumi $(\mathrm{J}), \mathrm{E}_{\mathrm{a}}$ adalah energi gempabumi yang seharusnya lepas dalam kurun waktu tertentu (erg/tahun, $\mathrm{E}_{\mathrm{b}}$ adalah jumlah energi yang sudah terlepas setelah gempabumi terbesar yang terjadi di wilayah penelitian (erg) dan $\mathrm{t}$ adalah rentang waktu perhitungan (tahun).

\subsection{Zona Subduksi}

Zona Subduksi merupakan pertemuan dua lempeng tektonik yang mempunyai berat jenis berbeda dan bergerak relatif saling mendekati, sehingga lempeng yang lebih berat menyusup atau menunjam ke bawah lempeng yang lebih ringan. Zona ini ditandai dengan adanya palung laut atau trench sebagai batas pertemuan kedua lempeng. Zona subduksi merupakan daerah zona seismik aktif, sebagian besar gempabumi terjadi di daerah ini, baik dangkal, menengah maupun dalam sebagai hasil dari penunjaman lempeng.

Secara tektonik, wilayah Bali bagian selatan merupakan bagian dari kerangka sistem tektonik Indonesia. Daerah ini termasuk dalam jalur gempa Mediteranian dan berada pada zone pertemuan lempeng tektonik. Pertemuan kedua lempeng ini bersifat konvergen dimana keduanya bertumbukan dan salah satunya yaitu lempeng Indo-Australia menunjam ke bawah lempeng Eurasia di mana Pulau Bali di atasnya. Subduksi lempeng Indo-Australia terhadap lempeng Eurasia dengan kecepatan berkisar antara 2$8 \mathrm{~cm}$ per tahun telah menghasilkan efek berupa struktur geologi sesar aktif di Daerah Bali dan sekitarnya [1].

\section{Metode Penelitian}

Penelitian ini dilakukan di Stasiun Geofisika Kelas II, Sanglah, Denpasar. Proses pengolahan data yaitu dengan menggunakan Sofware Arc GIS 10.8, Microsoft Excel 2016, Matlab 2017 dan Z-map 6. Data yang dipergunakan pada penelitian ini adalah data dari katalog gempabumi United State Geological Survey (USGS). Data yang dipergunakan adalah data periode gempabumi mulai dari tahun 1970-2020 di wilayah Bali koordinat $114,2^{\circ}-115,9^{\circ}$ BT dan $11,7^{\circ}-7,5^{\circ}$ LS pada magnitudo 3 hingga 10 . Langkah- 
langkah dalam penelitian ini dibagi menjadi lima langkah yaitu: Langkah pertama membuat peta seismisitas gempabumi yang terjadi di wilayah penelitian yang dilakukan yaitu men-download data gempabumi di wilayah penelitian website United State Geological Survey. Setelah itu menginput data gempabumi berupa data koordinat, magnitudo, dan kedalaman ke dalam program Ms. Excel. Kemudian memetakan data gempabumi menggunakan software ArGIS 10.8 dengan membagi data berdasarkan kedalaman, hiposenter dan magnitudo di Wilayah Bali tahun 1970-2020.

Langkah selanjutnya yang dilakukan yaitu untuk memperoleh a-value, b-value dan periode ulang gempabumi dilakukan konversi seluruh magnitudo gempabumi menjadi magnitudo momen $\left(\mathrm{M}_{\mathrm{w}}\right)$ dengan Persamaan 1 dan 2. Hal ini dilakukan karena magnitudo momen tidak mengalami saturasi. Sedangkan untuk memperoleh energi lepas, energi simpan dan energi potensial dilakukan konversi magnitudo gempabumi menjadi magnitudo bodi $\left(\mathrm{M}_{\mathrm{b}}\right)$ dengan menggunakan Persamaan 3. Selanjutnya yang dilakukan yaitu mem-filter data gempabumi dengan tujuan untuk menghilangkan pengaruh foreshock dan aftershock. Sehingga diperoleh gempabumi utama yang terjadi pada zona subduksi wilayah Bali dengan software Z-MAP 6.0. Kemudian menggelompokkan frekuensi gempabumi kedalam kelas sesuai dengan besarnya magnitudo gempabumi. Selanjutnya kejadian gempa dihitung berdasarkan magnitudonya dengan membuat kelas interval magnitudo. Terakhir yaitu a-value dan b-value dihitung dengan menggunakan Persamaan 8 dan 9. Kemudian untuk menghitung seismisitas dihitung dengan Persamaan 5 dan periode ulang gempabumi dihitung dengan menggunakan Persamaan 6. Indeks seismisitas dan periode ulang yang dihitung adalah gempabumi dengan magnitudo $6,8 \mathrm{M}_{\mathrm{w}}$ dengan magnitudo minimum atau $\mathrm{M}_{0} \geq 6 \mathrm{M}_{\mathrm{w}}$. Selanjutnya yaitu menghitung energi gempabumi dan energi kumulatif tahun 1970-2020 menggunakan Persamaan 11. Kemudian menghitung energi lepas pertahun $\left(E_{1}\right)$ dengan menggunakan Persamaan 13. Berikutnya energi ekspektasi total dihitung menggunakan gempabumi terbesar yaitu gempabumi yang terjadi pada tahun 2011 dengan magnitudo $6,8 \mathrm{M}_{\mathrm{w}}$. Untuk memperoleh energi ekspektasi total dilakukan konversi magnitudo $\mathrm{M}_{\mathrm{w}}$ ke momen seismik menggunakan persamaan 5 . Energi ekspektasi total dihitung dengan Persamaan 14. Energi ekspektasi total pertahun $\left(\mathrm{E}_{2}\right)$ diperoleh dengan cara membagi energi ekspektasi total dengan periode ulang. Terakhir yaitu menghitung energi gempabumi yang seharusnya lepas dalam kurun waktu tahun 2011-2020 ( $\left.\mathrm{E}_{\mathrm{a}}\right)$ dengan Persamaan 16. Jumlah energi yang sudah terlepas setelah gempabumi $\mathrm{M}_{\mathrm{w}}$ pada dihitung mulai dari tahun 2011-2020 $\left(\mathrm{E}_{\mathrm{b}}\right)$. Dan energi potensial gempabumi dihitung dengan Persamaan 15.

\section{Hasil Dan Pembahasan}

4.1 Hasil peta seismisitas Pulau Bali tahun 1970-2020

Berdasarkan data gempabumi yang terjadi di wilayah Bali yaitu sebanyak 397 kejadian gempabumi baik gempabumi mikro maupun sedang. Gempabumi pada wilayah penelitian terjadi pada kedalaman dangkal, menengah hingga dalam. Variasi kedalaman gempabumi berkisar mulai dari kedalaman $2 \mathrm{~km}$ hingga $332,5 \mathrm{~km}$. Gempabumi yang paling sering terjadi di wilayah penelitian yaitu pada kisaran magnitudo 4 $\mathrm{M}_{\mathrm{w}}$ seperti pada Gambar 1 dimana terdapat 259 kejadian gempabumi.

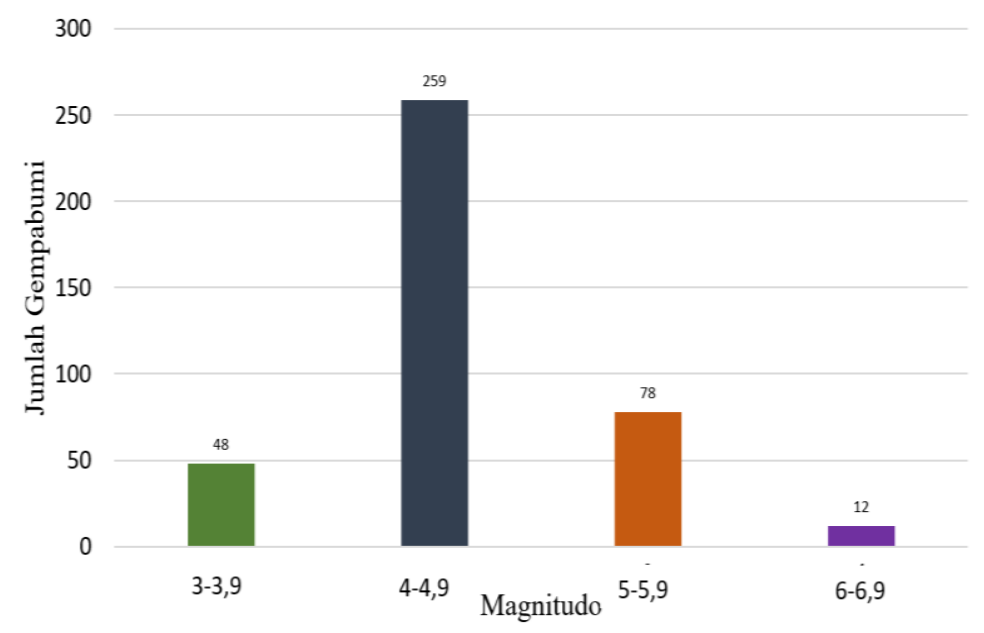

Gambar 1. Jumlah Kejadian Gempabumi Tahun 1970-2020 di Wilayah Bali. 
Terdapat sebanyak 383 kejadian gempabumi utama pada zona subduksi wilayah Bali setelah dilakukan filter data gempabumi dengan software ZMAP untuk menghilangkan pengaruh dari foreshock atau gempabumi sebelum gempa utama dan aftershock atau gempabumi susulan setelah gempabumi utama sehingga diperoleh data gempabumi utama atau mainshock. Seperti yang ditunjukkan pada Gambar 2 data peroleh tersebut dibagi menjadi beberapa kategori berdasarkan kedalaman serta magnitudo. Adapun kategori gempabumi dalam ditandai dengan menggunakan warna hijau, gempa menengah ditandai dengan warna kuning serta gempa dangkal ditandai dengan warna merah. Untuk gempabumi dengan magnitudo 1 hingga magnitudo 4,5 disimbolkan dengan bulatan kecil, sedangkan untuk magnitudo lebih besar dari 4,5 hingga magnitudo 7 disimbolkan dengan bulatan yang lebih besar. Peta seismisitas ini menggambarkan titik-titik episenter kejadian gempabumi yang terjadi di wilayah Bali.

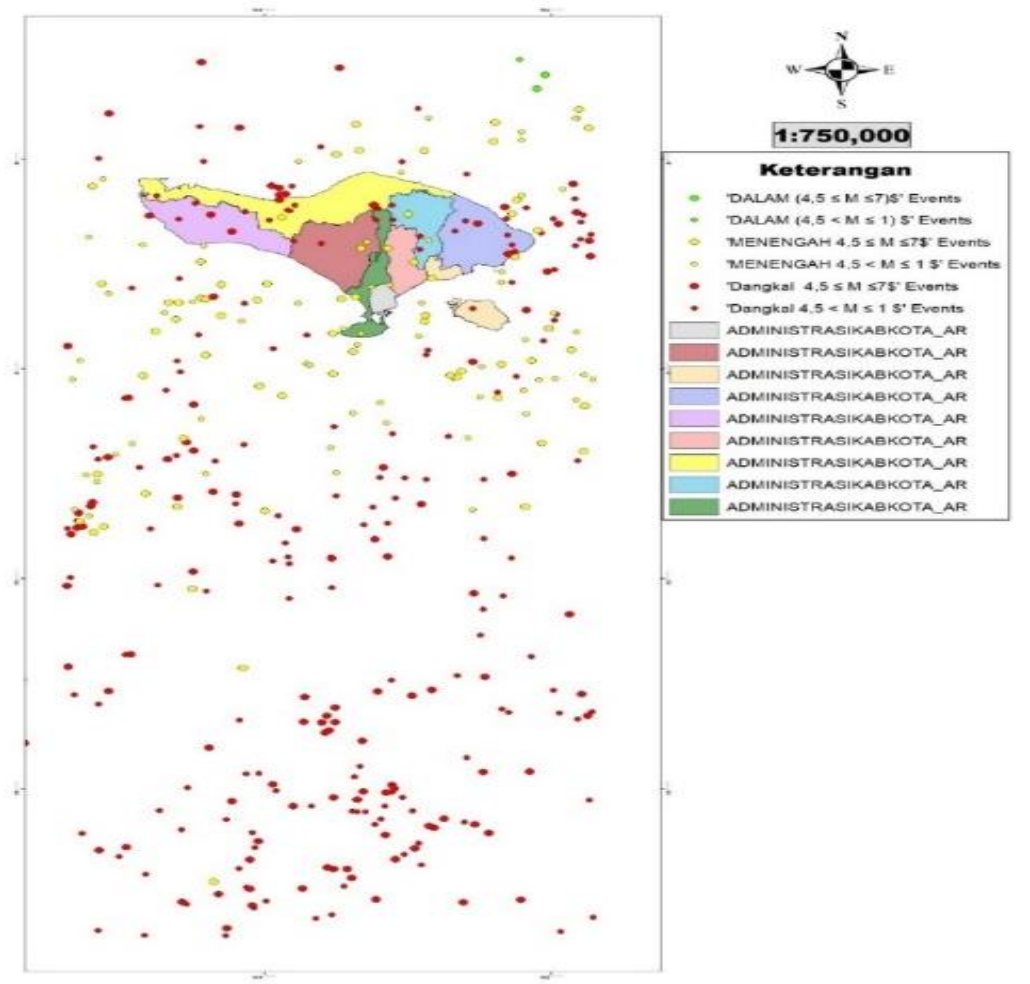

Gambar 2. Peta seis misitas Pulau Bali.

\subsection{Hasil analisis a-value dan b-value di Wilayah Bali}

Data dikelompokkan pada masing-masing kelas magnitudo seperti pada Tabel 1. Adapun rentang magnitudo yang digunakan dalam perhitungan parameter keaktifan gempabumi adalah rentang magnitudo 4,5 hingga magnitudo 5,6. Rentang magnitudo ini digunakan karena memiliki tingkat linearitas yang tinggi sesuai dengan hubungan antara frekuensi gempabumi dan magnitudo oleh Gutenberg dan Richter.

Tabel 1. Kelas interval magnitudo.

\begin{tabular}{llccccc}
\hline No & Magnitudo & $\begin{array}{c}\text { Nilai tengah magnitudo } \\
\left(\mathrm{X}_{\mathrm{i}}\right)\end{array}$ & $\begin{array}{c}\text { Jumlah kejadian } \\
\text { gempabumi }\left(\mathrm{Z}_{\mathrm{i}}\right)\end{array}$ & $\log \mathrm{Z}\left(\mathrm{Y}_{\mathrm{i}}\right)$ & $\mathrm{X}_{\mathrm{i}} \times \mathrm{Y}_{\mathrm{i}}$ & $\mathrm{X}_{\mathrm{i}}^{2}$ \\
\hline 1 & $4,5-4,7$ & 4,6 & 67 & 1,826 & 8,400 & 21,160 \\
2 & $4,8-5,0$ & 4,9 & 60 & 1,778 & 8,713 & 24,010 \\
3 & $5,1-5,3$ & 5,2 & 39 & 1,591 & 8,274 & 27,040 \\
4 & $5,4-5,6$ & 5,5 & 14 & 1,146 & 6,304 & 30,250 \\
& $\sum$ & 20,2 & 180 & 6,341 & 31,690 & 102,460 \\
\hline
\end{tabular}


Dari Tabel 1 maka dilakukan perhitungan a-value dan b-value. Adapun hasil analisis gempabumi pada tahun 1970-2020 diperoleh a-value $=5,3$ dan b-value $=-0,74$. Hasil dari parameter a-value yang diperoleh melalui perhitungan relatif sedang sehingga berkorelasi dengan aktivitas seismik atau jumlah kejadian gempabumi yang terjadi di wilayah penelitian secara keseluruhan termasuk sedang. Aktivitas seismik yang tinggi terjadi pada gempabumi dengan magnitudo $4 \mathrm{M}_{\mathrm{w}}$ hingga magnitudo $5 \mathrm{M}_{\mathrm{w}}$. Sedangkan b-value yang relatif rendah mengindikasikan bahwa kondisi batuan daerah zona subduksi di Pulau Bali secara umum solid sehingga menyimpan energi gempabumi yang besar. Kondisi ini dapat dijelaskan lebih lanjut dengan dihasilkannya energi ekspektasi pertahun yang jauh lebih besar dibandingkan dengan energi yang dilepaskan.

\subsection{Hasil analisis indeks seismisitas dan periode ulang gempabumi di Wilayah Bali}

Parameter aktivitas seismik (a-value) dan tingkat kerapuhan batuan (b-value) yang telah diperoleh dalam penelitian ini digunakan untuk memperoleh indeks seismisitas dan periode ulang. Berdasarkan hasil perhitungan, maka diperoleh hasil untuk daerah zona subduksi di Pulau Bali memiliki indeks seismisitas sebesar 0,083 serta mempunyai estimasi periode ulang gempabumi dengan magnitudo $M_{0}$ atau magnitudo batas baw ah yang diujikan $6 \mathrm{M}_{\mathrm{w}}$ sebesar 12 tahun. Untuk gempabumi dengan $\mathrm{M}_{0}<6 \mathrm{M}_{\mathrm{w}}$ atau $\mathrm{M}_{0}>6 \mathrm{M}_{\mathrm{w}}$ tidak dilakukan analisis pada penelitian ini mengingat keterbatasan data gempabumi yang terjadi di wilayah penelitian.

\subsection{Hasil analisis energi potensial}

Hasil perhitungan energi lepas gempabumi dihitung pada setiap kejadian gempabumi yang terjadi di wilayah penelitian. Untuk memperoleh energi lepas gempabumi pertahun dilakukan pengelompokan data gempabumi yang terjadi setiap tahun mulai dari tahun 1970-2020. Untuk memperoleh energi potensial gempabumi, maka dilakukan perhitungan energi lepas, energi ekspektasi dan energi total pertahun. Adapun energi gempabumi yang seharusnya lepas dalam kurun waktu gempa terbesar yang terjadi di wilayah penelitian hingga tahun $2020\left(\mathrm{E}_{\mathrm{a}}\right)$ yaitu sebesar 9,501 $\times 10^{14} \mathrm{~J}$. Adapun jumlah energi yang sudah terlepas setelah gempabumi terbesar hingga tahun 2020 yang terjadi di wilayah penelitian $\left(\mathrm{E}_{\mathrm{b}}\right)$ yakni sebesar $5,888 \times 10^{14} \mathrm{~J}$.

Adapun energi yang lepas pertahunnya yaitu sebesar $1,266 \times 10^{13} \mathrm{~J}$. Dengan mengasumsikan gempa besar yang terjadi pada tanggal 13 Oktober 2011 dengan episenter gempa pada 114,587 BT dan 9,35 LS dan berkekuatan $6,8 \mathrm{M}_{\mathrm{w}}$ sebagai energi ekspektasi yang tersimpan selama 12 tahun, maka didapatkan besarnya energi ekspektasi gempabumi $9,886 \times 10^{14} \mathrm{~J}$ dan energi ekspektasi pertahunnya sebesar 8,238 $\times$ $10^{13} \mathrm{~J}$. Jika dibandingkan dengan energi yang dilepas pertahun, energi ekspektasi gempabumi pertahun untuk wilayah Bali 6,5 kali lebih besar dari energi yang dilepas pertahun. Dengan menjumlahkan energi lepas gempabumi pertahun dan energi ekspektasi gempabumi pertahun, maka didapatkan besarnya energi total gempabumi pertahun yaitu sebesar $9,504 \times 10^{13} \mathrm{~J}$. Melalui perhitungan juga diperoleh energi potensial gempabumi untuk zona subduksi ini sebesar 3,616 $\times 10^{14} \mathrm{~J}$. Dengan adanya energi yang cukup besar pada zona subduksi di wilayah Bali menunjukan adanya kawasan seismic gap artinya kawasan ini menyimpan akumulasi energi gempabumi yang besar. Energi yang tersimpan ini dapat berpotensi menjadi gempabumi sedang pada kawasan zona subduksi di wilayah Bali.

\section{Kesimpulan}

Berdasarkan hasil analisis dan pembahasan, maka dapat ditarik kesimpulan antara lain, hasil analisis gempabumi pada tahun 1970-2020 di daerah zona subduksi di Pulau Bali pada koordinat $114,2^{\circ}-115,9^{\circ}$ BT dan $11,7^{\circ}-7,5^{\circ}$ LS diperoleh a-value $=5,3, \mathrm{~b}$-value $=-0,74$, dan indeks seismisitas 0,083 . Adapun estimasi periode ulang gempabumi dengan magnitudo $\mathrm{M}_{0}$ atau magnitudo batas baw ah yang digunakan untuk memperoleh periode ulang ini yaitu magnitudo $6 \mathrm{M}_{\mathrm{w}}$ sebesar 12 tahun. Untuk gempabumi dengan $\mathrm{M}_{0}<6 \mathrm{M}_{\mathrm{w}}$ atau $\mathrm{M}_{0}>7 \mathrm{M}_{\mathrm{w}}$ tidak dilakukan analisis pada penelitian ini mengingat keterbatasan data gempabumi yang terjadi di wilayah penelitian. Jadi periode ulang gempabumi ini berdasarkan perhitungan statistik data gempa yang pernah terjadi di wilayah penelitian khusus untuk gempabumi dengan magnitudo berkisar $6 \mathrm{M}_{\mathrm{w}}$. Setelah dilakukan perhitungan diperoleh energi potensial gempabumi untuk zona subduksi wilayah Bali sebesar $3,616 \times 10^{14} \mathrm{~J}$. 


\section{Ucapan Terima Kasih}

Penulis menyampaikan terimakasih kepada seluruh dosen beserta staf Program Studi Fisika, FMIPA, Universitas Udayana yang telah membimbing dan memberi saran dan masukan dalam penelitian ini. Kepala dan staf pegawai Stasiun Geofisika Kelas II Sanglah Denpasar yang telah membantu dalam memfasilitasi penelitian ini.

\section{Pustaka}

[1] T. Ardiansyah, Analisa Statistik Tingkat Keaktifan Gempa Bumi di Daerah Bali dan Nusa Tenggara, Skripsi, Akademi Meteorologi dan Geofisika, Jakarta, 2012.

[2] C. Demets, R.G. Gordon, D.F. Argus and S. Stein, Effect of Recent to The Geomagnetics Reversal Time Scale on Estimates of Current Plate Motions, Revisions Geophysical Research Letter, vol. 3, no. 21, 1994, pp. 2191-2194.

[3] T. Gunawan, Analisis Energi Gempabumi Daerah Tasikmalaya dan Sekitarnya. Skripsi. Akademi Meteorologi dan Geofisika, Jakarta, 2010.

[4] T. Gunawan, D. Aldilla, G. M. Taufik, Studi Karakteristik Gempabumi Signifikan Mw > 6.0 Akibat Aktivitas Sistem Busur Belakang Segmen Bali Lombok Menggunakan Analisis Energi Kumulatif dan Periode Ulang, Jurnal Meteorologi dan Geofisika, vol. 21, no. 2, 2020, pp. 29-35.

[5] B. Gutenberg, The Energy Of Earthquakes, The Quarterly Journal Of Geological Society Of London, vol. 112, no.3, 1955, pp. 19-28.

[6] N. Herlina, Tingkat Keaktifan Gempabumi Provinsi Maluku, Skripsi, Akademi Meteorologi dan Geofisika, Jakarta, 2012.

[7] Pusat Studi Gempa Nasional (PUSGEN), Peta Sumber dan Bahaya Gempa Indonesia Tahun 2017: Pusat Penelitian dan Pengembangan Perumahan dan Permukiman, Kementrian PUPR, Bandung, 2017.

[8] M. Raeis, and S. Syafriani, 2020, Analysis of Potential Earthquake Energy in The Sianok Segment, Journal of Physics: Conference Series, vol. 1 no. 1, 2020, pp. 1-9

[9] Sabar, A., 2014, Energi Potensial Gempabumi di Kawasan Segmen Mentawai-Sumatera Barat, Jurnal Meteorologi dan Geofisika, vol. 2 no. 1, 2014, pp. 1-9

[10] D. Sari, G. Khairina, Daniarsyad, Relokasi Hiposenter Gempabumi Menggunakan Metode Modified Joint Hypocenter Determination (MJHD) Untuk Analisis Zona Subduksi Sumatera Bagian Selatan, Jurnal Geofisika Eksplorasi, vol. 4, no. 1, 2018, pp. 16-25.

[11] Subardjo, dan Ibrahim, G., Pengetahuan Seismologi, Badan Meteorologi dan Geofisika, 2009.

[12] Malik, Analisa Pola Subduksi Daerah Bengkulu dengan Metode Segmen Irisan Vertikal, Skripsi, Akademi Meteorologi dan Geofisika, 2009.

[13] E. Suwandi, I dan Sari, Analisis Percepatan Tanah Maksimum, Intensitas Maksimum dan Periode Ulang Gempa untuk Menentukan Tingkat Kerentanan Seismik di Jawa Barat (Periode Data Gempa Tahun 1974-2016), Wahana Fisika, vol. 2, no. 2, 2017, pp. 12-30. 